\title{
SURVIVAL OF THE EPIGEAN DENDRODRILUS RUBIDUS TENUIS (OLIGOCHAETA: LUMBRICIDAE) IN A SUBTERRANEAN ENVIRONMENT
}

\author{
PREŽIVETJE POVRŠINSKEGA DEŽEVNIKA DENDRODRILUS \\ RUBIDUS TENUIS (OLIGOCHAETA: LUMBRICIDAE) V \\ PODZEMELJSKEM OKOLJU
}

Tone NOVAK $^{1 *}$, Csaba CSUZDI ${ }^{2}$, Franc JANŽEKOVIČ ${ }^{1}$, Tanja PIPAN ${ }^{3,5}$, Dušan DEVETAK ${ }^{1} \&$ Saša LIPOVŠEK ${ }^{1,4}$

\begin{abstract}
UDC 595.142:551.442(497.4Huda luknja) Tone Novak, Csaba Csuzdi, Franc Janžekovič, Tanja Pipan, Dušan Devetak \& Saša Lipov̌̌ek: Survival of the epigean Dendrodrilus rubidus tenuis (Oligochaeta: Lumbricidae) in a subterranean environment

The peregrine earthworm Dendrodrilus rubidus tenuis was regularly sampled in a percolating water drip originating in a habitat inaccessible to humans in the Huda luknja pri Doliču cave, Slovenia. The reconstruction of this habitat includes both a larger passage with bat colonies supplying wet bat guano sediments, on which the earthworms feed, and narrow channels, which drain water from this passage into the sampling drip. Fresh guano is deposited in autumn shortly before the earthworms become inactive. Then, it is exploited by moulds and additionally depleted by water washing out the nutrients before the earthworms reactivate in spring. Thus, this is a rather poor food resource for the earthworms. Despite this, and apart from their short size and delayed maturation, no other disturbance or damage was found caused by malnutrition, which was confirmed in individuals submitted to starvation in captivity. We suggest that $D d$. r. tenuis, which shows neither disturbance from nor adaptation to living in a subterranean environment, can subsist there because of its euryoecious character. Nevertheless, in temperate climates, this is rather a harsh habitat for this earthworm.
\end{abstract}

Keywords: dripping water, earthworms, karstic cave.
Izvleček UDK 595.142:551.442(497.4Huda luknja) Tone Novak, Csaba Csuzdi, Franc Janžekovič, Tanja Pipan, Dušan Devetak \& Saša Lipovšek: Preživetje površinskega deževnika Dendrodrilus rubidus tenuis (Oligochaeta: Lumbricidae) v podzemeljskem okolju

$\mathrm{V}$ vzorcih curka prenikajoče vode v Hudi luknji pri Doliču je bila peregrina vrsta deževnika Dendrodrilus rubidus tenuis redno prisotna. Curek doteka iz neznanega, človeku nedostopnega habitata. Na osnovi zbranih podatkov sklepamo, da sestoji ta habitat iz dveh habitatnih tipov. Prvi je večji rov s kolonijami netopirjev, ki proizvajajo gvano, s katerim se deževniki hranijo. Drugi je sistem ozkih kanalov, po katerih odteka voda iz tega rova v vzorčevani curek. Netopirji proizvedejo sveže gvano jeseni, malo preden deževniki prenehajo z aktivnostjo. Nato gvano izkoristijo plesni, dodatno se osiromaši zaradi kapljajoče vode, ki iz njega izpere nutriente, preden se spomladi deževniki reaktivirajo. To je torej zanje dokaj reven vir hrane. Kljub temu razen njihove kratke dolžine in poznega spolnega dozorevanja ne kažejo nobene motnje ali poškodbe, ki bi bile posledica slabe prehrane; enako smo ugotovili pri osebkih v ujetništvu. Predlagamo razlago, da lahko $D d$. $r$. tenuis, ki ne kaže niti motenj niti prilagoditev na življenje v podzemeljskem okolju, tam preživi zaradi svojega evriekega značaja. Kljub temu so razmere v podzemeljskem okolju v območjih z zmernim podnebjem za to vrsto dokaj ostre.

Ključne besede: deževniki, kraška jama, prenikajoča voda.

\footnotetext{
${ }^{1}$ Department of Biology, Faculty of Natural Sciences and Mathematics, University of Maribor, Koroška cesta 160, SI-2000 Maribor, Slovenia,e-mail: tone.novak@um.si; franc.janzekovic@um.si; dusan.devetak@um.si

${ }^{2}$ H-2081 Piliscsaba, Kenderesi str. 13, Hungary, e-mail: csuzdi01@gmail.com

${ }^{3}$ Karst Research Institute, Scientific Research Centre of the Slovenian Academy of Sciences and Arts, Titov trg 2, SI-6230 Postojna, Slovenia, e-mail: pipan@zrc-sazu.si

${ }^{4}$ Medical Faculty, University of Maribor, Taborska ulica 8, SI-2000 Maribor, Slovenia, e-mail: sasa.lipovsek@uni-mb.si

${ }^{5}$ University of Nova Gorica, Vipavska 13, Rožna dolina, SI-5000 Nova Gorica, Slovenia
}

Received/Prejeto: 11.03.2013 


\section{INTRODUCTION}

A dozen lumbricid species have been reported exclusively from caves, such as Allolobophora cryptocystis Černosvitov, 1935, Helodrilus kratochvili (Černosvitov, 1935), and H. mozsaryorum (Zicsi, 1974), mostly as single finds. Some have later been recognized as accidental individuals of epigean species (Černosvitov 1939, Pop 1968, Zicsi 1974, Dumnicka \& Juberthie 1994). In central and northern Slovenia, 17 lumbricid species and one subspecies have been occasionally recorded in caves and artificial tunnels (Mršić 1990a, 1990b; Novak 2005). These are Allolobophora leoni (Michaelsen, 1891), Aporrectodea rosea (Savigny, 1826), Ap. smaragdina (Rosa, 1892), Dendrobaena byblica (Rosa, 1893), D. octaedra (Savigny, 1826), Dendrodrilus r. rubidus (Savigny, 1826), Dd. r. tenuis (Eisen, 1874), Eisenia lucens (Waga, 1857), E. spelaea (Rosa, 1901), Eiseniella t. tetraedra (Savigny, 1826), Lumbricus castaneus (Savigny, 1826), L. r. rubellus Hoffmeister, 1843, Octodrilus transpadanus (Rosa, 1884), O. meroandricus Mršić, 1985, Octodriloides kamnensis (Baldasseroni, 1919), O. zupancici Mršić, 1987, Octolasion l. lacteum (Örley, 1881) and Proctodrilus antipae (Michaelsen, 1891). Zicsi (1974) declared H. mozsaryorum from the famous Hungarian cave Baradla to be a troglobiotic aquatic species, although he did not exclude the possibility of its finding in surface habitat in the future. However, despite the intensive research carried out in the Aggtelek karstic region, H. mozsaryorum has not been found in surface habitats; therefore, the troglobiotic nature of this species was later corroborated (Zicsi et al.
1999). Beside this species, no other exclusively cavernicolous lumbricid earthworm is known so far (Dumnicka in lit.).

Hypogean communities of epigean earthworm species can always be found in caves among accumulations of various types of organic matter, like torrential deposits and the sediments of underground watercourses and guano (Dumnicka \& Juberthie 1994; Sambugar \& Sket 2004; Dumnicka 2005). After the discovery of the importance of epikarst for subterranean biota (Pipan 2005), intensive investigations of this habitat started in Slovenia and the USA (Pipan et al. 2006, 2008; Pipan \& Culver 2005, 2007a, 2007b; Culver \& Pipan 2008, 2014). During similar investigation of the fauna in percolating water drips in a cave in northern Slovenia, we found a viable population of Dendrodrilus rubidus tenuis (Lumbricids in Pipan et al. 2008). Cave-dwelling, troglophile populations of this species have also been reported from other caves (McAlpine \& Reynolds 1977; Reeves et al. 1999). Our present scope is to analyze the main parameters allowing this epigean earthworm species to survive in a subterranean habitat, and to reconstruct the environmental features of this hypogean habitat inaccessible to humans. For this purpose, we considered both the dripping water data, and the physical condition of the Dendrodrilus specimens found in the drip. We hypothesized a rich food resource supply in the habitat, which is crucial for the survival of the earthworms.

\section{MATERIAL AND METHODS}

Systematic monthly sampling of water from 12 trickles was carried out in the Medvedji rov passage in the Huda luknja pri Doliču cave (Fig. 1; entrance 46 $24^{\prime} 53^{\prime \prime} \mathrm{N}$, $15^{\circ} 10^{\prime} 44^{\prime \prime}$ E, altitude $508 \mathrm{~m}$ ) from November 2005 till October 2006 (details in Pipan et al. 2008). These trickles provided different types of percolating water: a tiny permanent current (min ca. $0.5 \mathrm{dL}^{\text {day }}{ }^{-1}$ ), constant dripping water $\left(0.05-0.2 \mathrm{dL} \mathrm{sec}^{-1}\right)$ and drips immediately reacting to precipitation (up to $1.5 \mathrm{dL} \mathrm{sec}^{-1}$ ). Water drips were collected using a funnel $30 \mathrm{~cm}$ in diameter into a $15 \mathrm{~cm}$ high container of $10 \mathrm{~cm}$ diameter, with side overflow holes covered with net (mesh size $60 \mu \mathrm{m}$ ) to retain the animals and solid particles. The water temperature was measured in situ; concentrations of $\mathrm{Na}^{+}, \mathrm{K}^{+}, \mathrm{Ca}^{2+}, \mathrm{Mg}^{2+}$, $\mathrm{Cl}^{-}, \mathrm{NO}_{3}^{-}$and $\mathrm{SO}_{4}^{2-}$ ions as well as $\mathrm{Ca}$ - and total hardness, and conductivity were determined using Standard Meth- ods for the Examination of Water and Wastewater (1989) in the laboratory. The samples of fauna were fixed in situ with formaldehyde to a final concentration of $2-3 \%$. After extraction, the organisms were stored in $70 \%$ ethanol. To provide further information on earthworms, each bat guano accumulation in the cave and the "lumbricidtrickle" in control were additionally inspected for lumbricids 14 times between 2006 and 2009. The fauna of the small water pools formed in guano piles by trickling water was sampled using a spoon.

For light microscopy, three earthworms were treated immediately with gut contents intact, and two were kept alive on a water-gelatine gel, analogous to the water-agar gel method (Pokarzhevskii et al. 2000), for four days at $8{ }^{\circ} \mathrm{C}$ until the gut content was voided. The earthworms were fixed in $2.45 \%$ glutaraldehyde and 


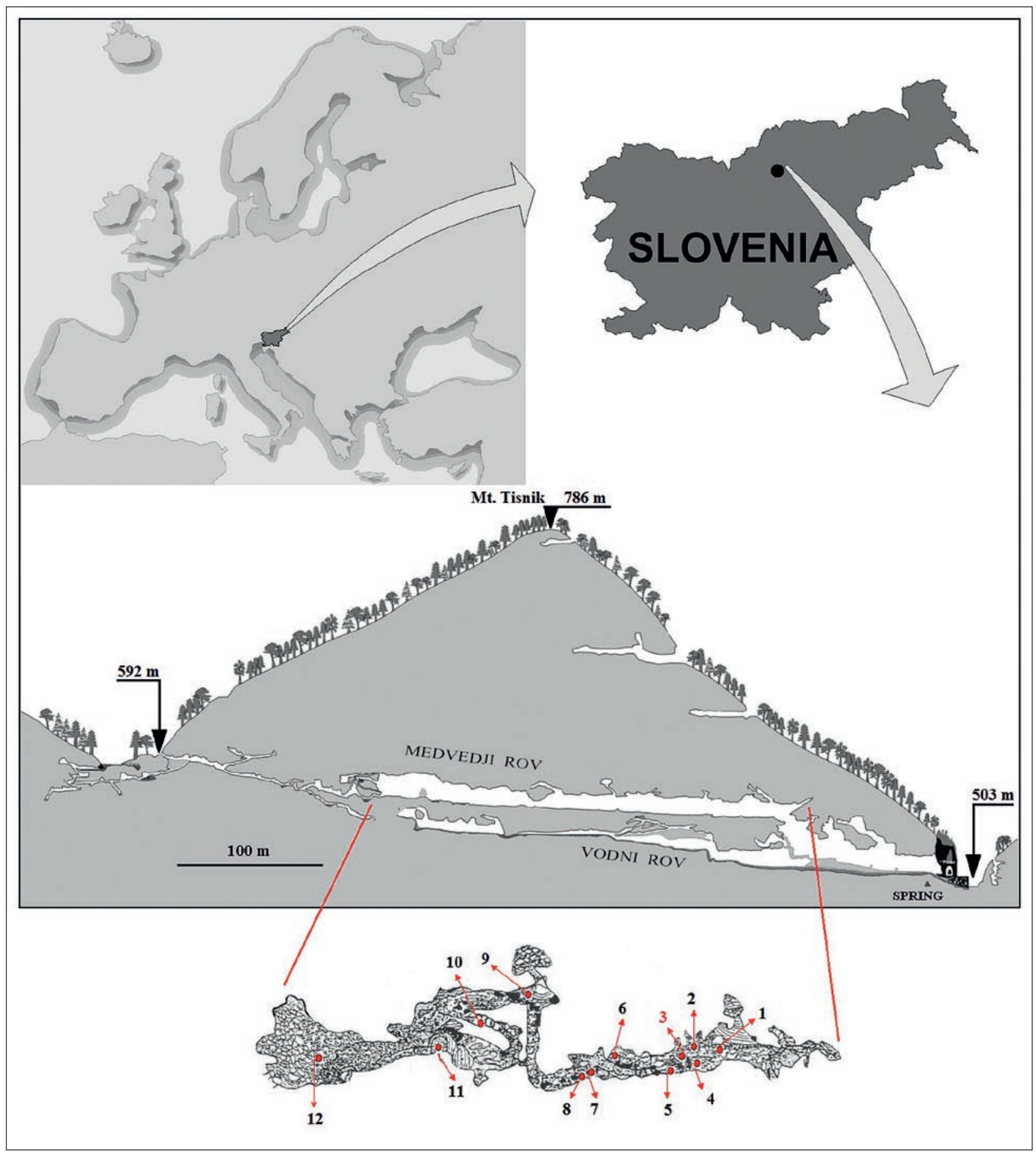

Fig. 1: Geographical location and the longitudinal section of the Huda luknja cave system with the ground plan of the Medvedji rov passage; from Pipan et al. (2008), partly modified. Courtesy Acta Carsologica.

$2.45 \%$ paraformaldehyde in a $0.1 \mathrm{M}$ sodium cacodylate buffer ( $\mathrm{pH}$ 7.3), at room temperature for $3 \mathrm{hrs}$, and at $4{ }^{\circ} \mathrm{C}$ for $12 \mathrm{hrs}$. The samples were washed in a $0.1 \mathrm{M}$ sodium cacodylate buffer ( $\mathrm{pH}$ 7.3), at room temperature for $3 \mathrm{hrs}$, postfixed with $2 \% \mathrm{OsO}_{4}$, at room temperature for $2 \mathrm{hrs}$ and dehydrated in a graded series of ethanol $(50,70,90,96,100 \%$, each for $30 \mathrm{~min}$ at room temperature). Tissue samples were embedded in TAAB epoxy resin (Agar Scientific Ltd., Essex, England). Semi-thin sections $(5 \mu \mathrm{m})$ were cut and stained with $0.5 \%$ tolui- 
dine blue in aqueous solution. After staining, the tissue was analyzed with a Nikon Eclipse E800 microscope. 22 individuals were measured for their length, width and number of segments.

Additionally, from February $26^{\text {th }}$ till June $25^{\text {th }} 2007$, seven earthworms were kept in a refrigerator at $8{ }^{\circ} \mathrm{C}$ to provide information about their behavior. The specimens were kept in a $1.5 \mathrm{dL}$ vessel with $2 \mathrm{~cm}$ deep water from the trickle, and with a piece of folded toilet paper, half of it projecting above the water surface. No food was added. The worms were inspected once a week (14 observations in total) for their placement selection in or outside the water, and their gregariousness, controlling at the same time their condition to cease the observation immediately, if any sign of disturbance would appear.

Descriptive statistics was used to evaluate the physical and chemical characteristics of the drips, as well as the main morphological characteristics of the worms. A t-test for independent samples was used in testing the differences between the drip with and those without Dendrodrilus for each physical and chemical parameter (Legendre \& Legendre 2012). The program SPSS 21.0 for Windows was used in the statistical procedures.

\section{RESULTS}

During one-year monthly sampling, we found Dendrodrilus specimens in only one of the 12 trickles sampled (No. 3 in Fig. 1) from April till October with an abundance peak in June, while they were absent during winter. Trickle No. 3 (hereinafter Dendrodrilus drip) and two other trickles (No. 6, 10) had similar permanent discharge slightly varying throughout the year (ca. $0.05-0.1 \mathrm{dL} \mathrm{sec}^{-1}$ ), but they differed in other parameters (details in Pipan et al. 2008). Ca- and total hardness (TH), and conductivity (con.) in the Dendrodrilus drip were constantly significantly higher with respect to other drips (Ca: $\mathrm{t}=16.10, \mathrm{TH}: \mathrm{t}=17.49$, con.: $\mathrm{t}=6.33$, $\mathrm{df}=276$, $\mathrm{p}<0.0001$ ) (Fig. 2) in every month of the worm's activity in the hypogean habitat. In other parameters these differences either alternated between the Dendrodrilus drip and the other drips (temperature, $\mathrm{K}^{+}, \mathrm{Ca}^{2+}, \mathrm{SO}_{4}^{2-}$ ), or did not differ significantly $\left(\mathrm{pH}, \mathrm{Na}^{+}, \mathrm{Mg}^{2+}\right)$. Besides, in the Dendrodrilus drip, $\mathrm{NO}_{3}^{-}$values drastically increased from August till October, and $\mathrm{Cl}^{-}$values in September and October (Fig. 2); these values were both significantly different from the other drips $\left(\mathrm{NO}_{3}^{-} \mathrm{t}=4.84, \mathrm{Cl}^{-} \mathrm{t}=4.61, \mathrm{df}=276\right.$, $\mathrm{p}<0.0001)$.

In the relatively pure water collected in the vessel during continuous percolation, all specimens were alive. During dry periods, a few of them died because the water in the vessel was polluted with fresh bat droppings.
Those earthworms that escaped and crawled up the vessel walls above the water survived. After 2006 we collected nine juveniles from the Dendrodrilus drip. On May 16,2009 , for the first time, two individuals-one of them adult-were found in a little pool eroded by trickling water in a guano pile a few meters from the trickle, and one juvenile was observed on June 17, 2009 (Fig. 3). Only in this guano accumulation Dendrodrilus were found.

In the trickle, 22 individuals measured 15.0 \pm 1.7 (12.1-17.0) $\mathrm{mm}$ in length and were $1.8 \pm 0.2(1.6-2.0)$ mm wide, counting 96 (79-105) segments. The adult worm found on 29.5.2007 was $28.0 \mathrm{~mm}$ long and had 99 segments.

In the refrigerator, all specimens crept into the submerged, tightly folded paper and were permanently crowded together, with the exception of one or two individuals $1-3 \mathrm{~cm}$ away. Whenever the paper was turned upside down, i.e., the immersed earthworms were turned to the air, they crawled into the lower, immersed folds within a minute. While stretching parts of their body, the earthworms elongated these parts 4-5-times their entire length and became correspondingly thinner. They fed on the paper, and all survived four months without any evident disturbance or damage. All specimens were fully fed and of normal appearance with simple, low and wide typhlosole (Fig. 4). 


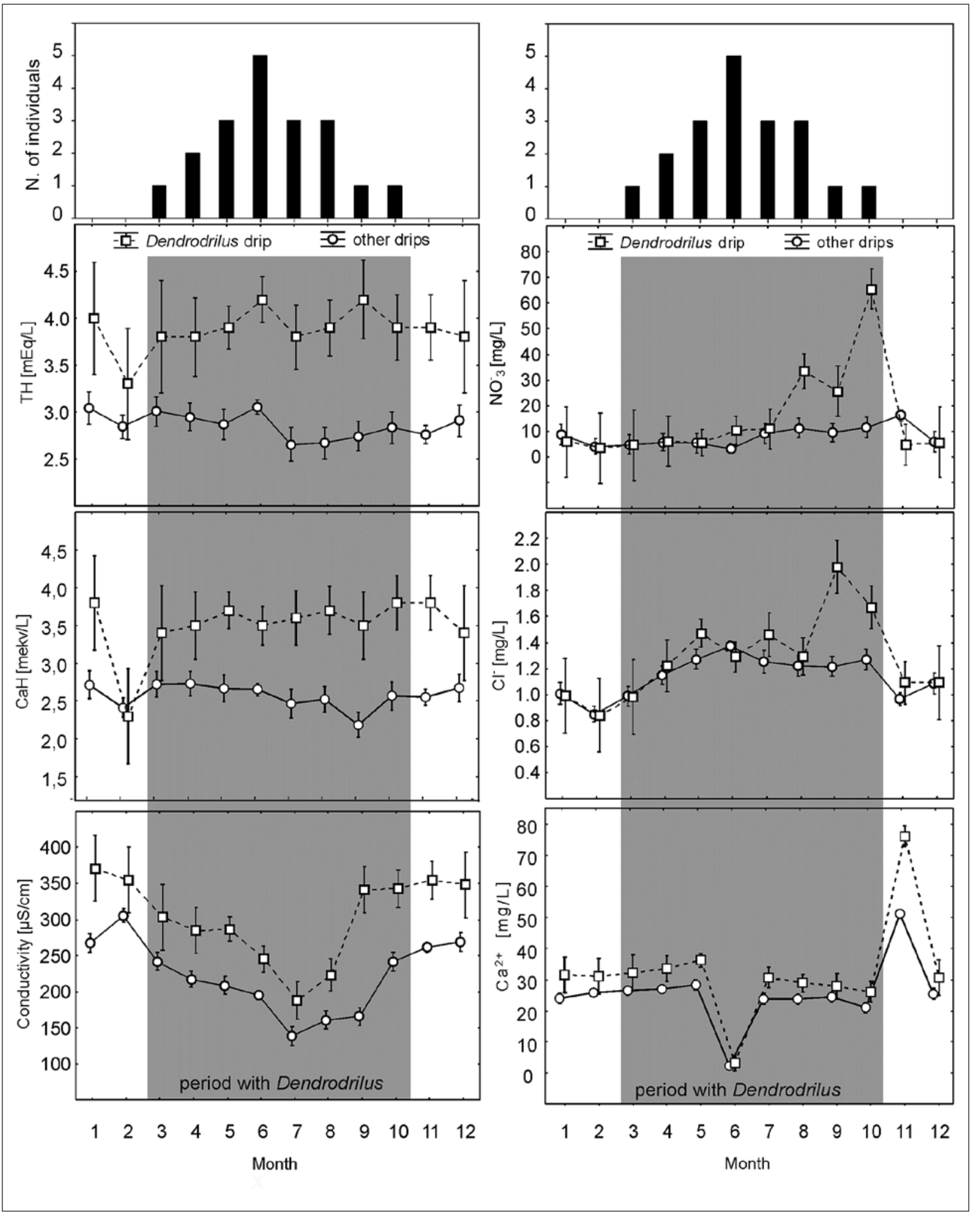

Fig. 2: Total (TH) and calcium hardness $(\mathrm{CaH})$, conductivity, nitrate $\left(\mathrm{NO}_{3}^{-}\right)$, chloride $\left(\mathrm{Cl}^{-}\right)$and calcium $\left(\mathrm{Ca}^{2+}\right)$ in the Dendrodrilus drip vs. other drips. 


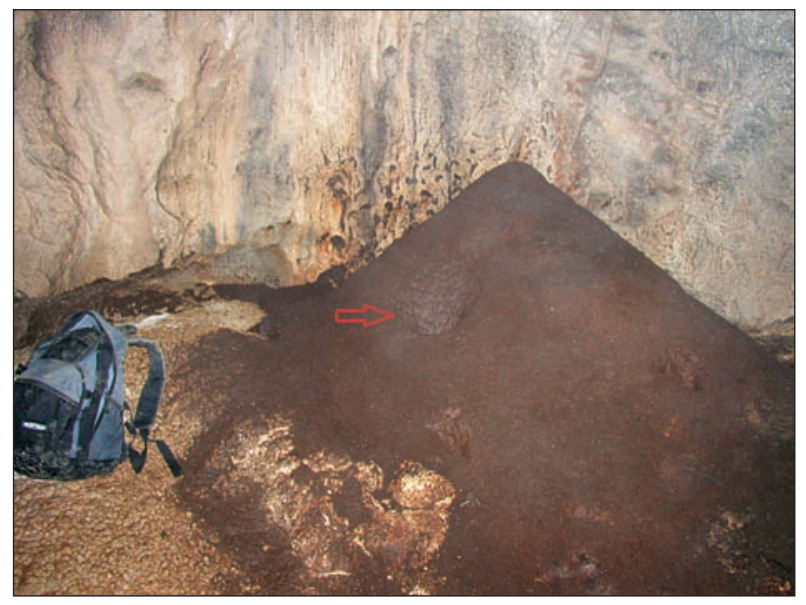

Fig. 3: Pits made by dripping water in a bat guano pile, where an adult Dendrodrilus rubidus tenuis was found.

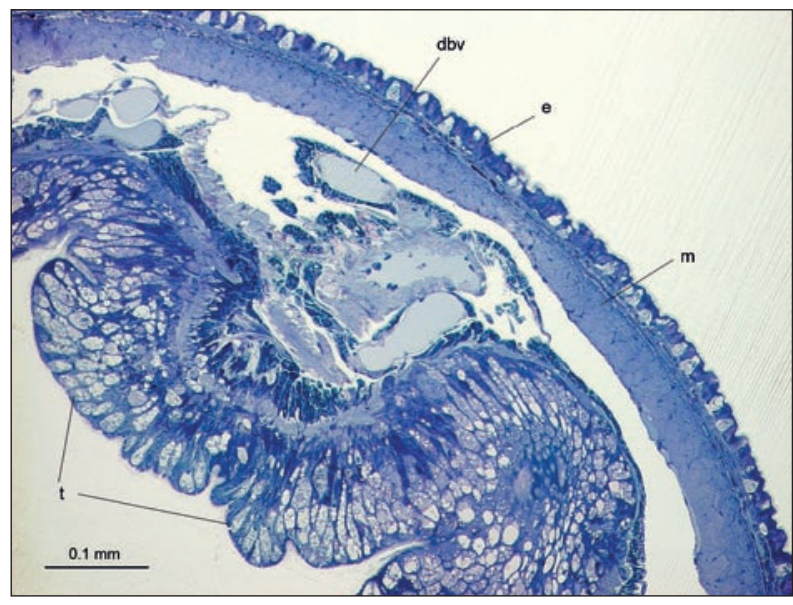

Fig. 4: Dendrodrilus rubidus tenuis, typhlosole in the $40^{\text {th }}$ segment of a representative specimen. e epidermis, $m$ longitudinal muscle layer, dbv dorsal blood vesel, $t$ typhlosole.

\section{DISCUSSION}

Individuals of $D d$. r. tenuis retrieved from the dripping water had drifted there from an unknown subterranean habitat above the sampling passage. This terrestrial species most likely preferred a substrate soaked with water. According to chemical analysis of the trickling water, this habitat has two specific properties that are distinct from the other seeps without earthworms. First, it is supplied by annually fluctuating, large quantities of fresh organic matter, the volume of which starts to rise in August, culminating in October. This is evident from the $\mathrm{NO}_{3}^{-}$and $\mathrm{Cl}^{-}$increases, which perfectly match the defecation and urination patterns of the progressively enlarging colony of the Bent-wing Bat, Miniopterus schreibersii (Kuhl, 1817), up to 2000 individuals. Most of these bats then suddenly moved to an unknown passage to overwinter and roost; most probably, the trickling water flows from there. Second, the particular drip is characterized by the highest values of Ca- and total hardness as well as conductivity. There could be a few reasons for higher values: 1 . Water flowing from the sites with overwintering bats passes through narrow spaces with relatively high $\mathrm{CO}_{2}$ pressure, which in turn enhances the water's dissolving capacity. 2. Longer residence time of the water caught underground for a long period in contact with the limestone bedrock provided higher saturation state, and hence higher values of both hardnesses and conductivity. 3. Presence of other ions such as $\mathrm{Cl}^{-}$and $\mathrm{NO}_{3}^{-}$caused higher equilibrium and consequently higher conductivity. Any of these or their combination could be the reason.
Theoretically, the hypogean characteristics of lumbricid species in carbonate rocks are their small size and a reduction in a number of organs, like testicles, spermathecae etc. (Dumnicka 1986; Dumnicka \& Juberthie 1994), the hindrance or reduction of reproductive seasonality and its internal regulation (Rozen 2006), and, presumably, intensive activity of the calciferous glands (Robertson 1936, Canti \& Pearce 2003). However, in this case, the reduction of the genital organs could also be due to the well-known parthenogenetic reproduction of $D d$. r. tenuis. Besides, as a consequence of feeding on poor food resources, more extensive branching of the typhlosole may be expected in specialized hypogean species. Since fresh guano was deposited in the period when Dendrodrilus were carrying out their annual activity, they were able to exploit this resource to a limited extent. Later, the guano was exploited by moulds, while percolating water additionally washed out soluble compounds, leaving behind an energy-poor resource for the earthworms in spring. In this population of $D d$. $r$. tenuis, small size and the large ratio of immature individuals are considered the direct consequence of malnutrition caused by such impoverishment of the substrate, while no hindrance in development, enlargement of the typhlosole and malformation of or damage to other organs was noticed. Moreover, surviving a four-month period of starvation in captivity without damage demonstrates that $D d$. $r$. tenuis - reported to inhabit litter and organically enriched surface soil layers (Hendrix \& Bohlen 2002) - is well adapted to poor food resources, 
as well. Additionally, the capacity for extreme elongation and narrowing may be an adaptation for living in systems consisting of narrow spaces, as can be expected in the rhizosphere and epikarst (Culver \& Pipan 2009; Novak et al. 2012), or might be an adaptation to exploit more efficiently the water-solved oxygen. Their ability to crawl out of the water demonstrates that $D d$. $r$. tenuis can leave an inappropriate habitat, and search for an appropriate microhabitat. Adult $D d$. $r$. tenuis do not survive temperatures below $0{ }^{\circ} \mathrm{C}$ and do not overwinter in cold climates (Berman et al. 2010), while the adult found in May suggests that the species may overwinter in hypogean habitats. This is likely to be the case in Central Europe, where earthworms overwinter deeper in the soil. It is thus either death or overwintering that caused their absence from the samples during winter. All these denote that $D d$. r. tenuis is a euryoecious rather than a specialized species, which helps in an understanding of its invasive character (cf. Global Invasive Species Database).

\section{CONCLUSIONS}

Most likely, the reconstruction of this sampling site with Dendrodrilus rubidus tenuis is as follows: an undiscovered passage with bat guano accumulation somewhere above this particular passage is settled by the earthworms, from where water passes through narrow channels and drips into the passage under investigation. The narrow channels with percolating water function as merely a connecting habitat between the spacious habitat providing the guano and the sampling site in the gallery being investigated. Dendrodrilus shows a high tolerance to such energy-poor food resource, but no special adaptation to or damage from living in a subterranean habitat. Although this represents rather a harsh habitat for these earthworms, they can survive in such habitats with bat guano deposits and a permanent water supply.

\section{ACKNOWLEDGEMENTS}

We are indebted to the staff of the chemical laboratory of the Šoštanj Steam Power Station where the chemical analyses were carried out, especially to Mrs. G. Srnovršnik. We are grateful to V. Navodnik, V. Ocvirk and L. Slana Novak who helped with the field work, and to the cavers of the Speleos-Siga Cavers' Club in Velenje for the sup- port in the investigations. We sincerely thank two anonymous referees for insightful comments and suggestions, and Michelle Gadpaille for valuable improvements to the language. The study was partly supported by the Slovenian Research Agency within the Biodiversity Research Programme (P1-0078).

\section{REFERENCES}

Berman, D.I., Meshcheryakova, E.N. \& A.N. Leirikh, 2010: Egg cocoons of the earthworm Dendrodrilus rubidus tenuis (Lumbricidae, Oligochaeta) withstand the temperature of liquid nitrogen.- Doklady Biological Sciences 434, 347-350.

Canti, M.G. \& T.G. Pearce, 2003: Morphology and dynamics of calcium carbonate granules produced by different earthworm species.- Pedobiologia 47, 511-521.
Culver, D.C. \& T. Pipan, 2008: Superficial subterranean habitats - gateway to the subterranean realm?- Cave and Karst Science 35, 5-12.

Culver, D.C. \& T. Pipan, 2009: The Biology of Caves and Other Subterranean Habitats. Oxford University Press, 256 pp., Oxford, New York.

Culver, D.C. \& T. Pipan, 2014: Shallow Subterranean Habitats. Oxford University Press, 258 pp., Oxford, New York. 
Černosvitov, I., 1939: Etudes biospéologiques - X(1). Catalogue des Oligochètes hypogés.- Buletin du Museum Royal de Histoire Naturelle de Belgique $15,1-92$.

Dumnicka, E., 1986: Naididae (Oligochaeta) from subterranean waters of West Indian Islands; distribution, taxonomic remarks and description of a new species.- Bijdrage Dierk 6, 267-281.

Dumnicka, E., 2005: Worms.- In: Culver, D. C. \& W. B. White (eds.): Encyclopaedia of Caves. Elsevier, pp. 614-618.

Dumnicka, E. \& C. Juberthie, 1994: Aphanoneura et Oligochaeta.- In: Juberthie, C. \& V. Decu (eds.), Encyclopaedia biospeologica, pp. 67-75, Société de Biospéologie, Moulis - Bucarest.

Global Invasive Species Database-[Online] Available from: http://www.issg.org/database/welcome/ [Accessed $3^{\text {rd }}$ June 2014.]

Hendrix, F.P. \& P.J. Bohlen, 2002: Exotic Earthworm Invasions in North America: Ecological and Policy Implications.- BioScience 52, 801-809.

Legendre, P. \& J. Legendre, 2012: Numerical Ecology. Elsevier, 990 pp., Amsterdam.

McAlpine, D.F. \& J.W. Reynolds, 1977: Terrestrial Oligochaeta of some New Brunswick Caves with remarks on their ecology.- Canadina Field-Naturalist 91, 360-366.

Mršić, N., 1991a: Monograph on earthworms (Lumbricidae) of the Balkans I. Opera SAZU 31, pp. 1-355, Ljubljana.

Mršić, N., 1991b: Monograph on earthworms (Lumbricidae) of the Balkans II. Opera SAZU 31, pp. 356-757, Ljubljana.

Novak, T., 2005: Terrestrial fauna from cavities in northern and central Slovenia, and a review of systematically ecologically investigated cavities.- Acta Carsologica 34,169-210.

Novak, T., Perc, M., Lipovšek, S. \& F. Janžekovič, 2012: Duality of terrestrial subterranean fauna.- International Journal of Speleology 41, 181-188.

Pipan, T., 2005: Epikarst - a promising habitat.- Carsologica, Založba ZRC SAZU, 101 pp., Ljubljana,

Pipan, T., Blejec, A. \& A. Brancelj, 2006: Multivariate analysis of copepod assemblages in epikarstic waters of some Slovenian caves.- Hydrobiologia 559, 213-223.

Pipan, T. \& D.C. Culver, 2005: Estimating biodiversity in the epikarstic zone of a West Virginia cave.- Journal of Cave and Karst Studies 67, 103-109.
Pipan, T. \& D.C. Culver, 2007a: Copepod distribution as an indicator of epikarst system connectivity.- Hydrogeology Journal 15, 817-822.

Pipan, T. \& D.C. Culver, 2007b: Regional species richness in an obligate subterranean dwelling fauna epikarst copepods.- Journal of Biogeography 34, 854-861.

Pipan, T., Navodnik, V., Janžekovič, F. \& T. Novak, 2008: Studies of the fauna of percolation water of Huda luknja, a cave in isolated karst in Northeast Slovenia.- Acta Carsologica 37, 141-151.

Pokarzhevskii, A.D., Van Straalen, N.M. \& A.M. Semenov, 2000: Agar as a medium for removing soil from earthworm guts.- Soil Biology \& Biochemistry 32, 1315-1317.

Pop, V., 1968: Les Lumbricides cavernicoles de la Collection Biospeologica.- Archives de Zoologie Éxperimentale et Générale 109, 229-256.

Reeves, W., Reynolds, K., \& J. Warren, 1999: New records of cave-dwelling earthworms (Oligochaeta: Lumbricidae, Megascolecidae and Naididae) and other annelids (Aeolosomatida, Branchiobdellida and Hirudinea) in the Southeastern United States, with notes on their ecology.- Megadrilogica 7, 65-71.

Robertson, J.D., 1996: The function of the calciferous glands of earthworms.- Journal of Experimental Biology 13, 279-297.

Rozen, A., 2006: Internal regulation of reproduction seasonality in earthworm Dendrobaena octaedra (Savigny, 1826) (Lumbricidae, Oligochaeta).- Soil Biology \& Biochemistry 38, 180-182.

Sambugar, B. \& B. Sket, 2004: Annelida.- In: Gunn, J. (ed.), Encyclopaedia of Caves and Karst Science, pp. 66-68, Taylor \& Francis.

SPSS 21.0 for Windows.

Standard Methods for the Examination of Water and Wastewater, $17^{\text {th }}$ ed., APHA-AWWA-WPCF (1989), 1088 pp.

Zicsi, A., 1974: Ein neuer Höhlen-Regenwurm (Oligochaeta: Lumbricidae) aus Ungarn.- Acta zoologica Academiae Scientiorum Hungaricae 20, 227-232.

Zicsi, A., Dózse-Farkas, K. \& Cs. Csuzdi, 1999: Terrestrial Oligochaetes of the Aggtelek National Park.- In: Mahunka, S. (ed.): The Fauna of the Aggtelek National Park, Hungarian Natural History Museum, pp. 39-43, Budapest. 